\title{
Fulvic acids generated in municipal waste landfills in Promnik
}

\author{
Tomasz Orliński ${ }^{1, *}$, and Anna M. Anielak ${ }^{1}$ \\ ${ }^{1}$ Department of Environmental Engineering, Institute of Water Supply and Environmental Protection, \\ Cracow University of Technology, ul. Warszawska 24, 31-155 Cracow, Poland
}

\begin{abstract}
Landfill leachates are resistant to biodegradation, contain substances harmful to the environment, which is why they are troublesome in the water and sewage management. The study tested the leachate from the municipal waste landfill in Promnik, whose age of waste disposal is 33 years. The research consisted of extracting from average leachates (with a volume of $800 \mathrm{~m}^{3}$ ) fulvic acids resistant to biodegradation. The extraction of acids was carried out using a hydrophobic and hydrophilic ionite in a hydrogen form. The extracted fulvic acids (FAs) was subjected to qualitative analysis on the content of micro-pollutants and the content of elementary elements forming the structure of the FAs molecule, their infrared and UV-VIS spectra were examined. Then, a full analysis of the obtained values was carried out in order to determine the properties of the obtained extractant and demonstrate the convergence of its features with humus substances that are common in the environment, which are an important element of soils, affect their quality and participate in the transport of plant nutrients. It was demonstrated that the concentration of FAs in the effluent is $905.6 \mathrm{mg} / \mathrm{l}$.
\end{abstract}

\section{Introduction}

According to the definition contained in art. 3 par. 1 of Directive 2008/98/EC, "waste means any substance or object which the holder discards or intends or is required to discard" [1]. In 2017, the average Pole generated $307 \mathrm{~kg}$ of municipal waste, which is $7.3 \%$ more than in 2015. With regard to the inhabitants of European countries, Poland has one of the lowest rates of waste generated. In EU countries, each resident generates approximately $482 \mathrm{~kg}$ of municipal waste [2]. Each year, the amount of waste generated increases, creating a huge problem with waste management.

Waste is subjected to disposal processes, i.e. biological, physical and chemical processes in order to bring them to a condition that does not pose a threat to human life or health and the environment. These processes include: landfilling, incineration, gasification and pyrolysis and processing into solid fuel. The oldest and most popular method of waste

\footnotetext{
* Corresponding author: t.orlinski1990@gmail.com
} 
disposal is landfilling. In Poland in 2016, 37\% of the total amount of waste generated was allocated for landfilling (i.e. 4.3 million tonnes) [3].

Landfilling of waste generates leachate containing many hazardous substances in high concentrations. The composition and properties of leachate depend on the age of the landfill, the type of waste, climatic conditions and the operating mode of the landfill [4]. A significant part of the waste deposited undergoes so-called humification. The humification process stabilizes the organic matter in the waste deposit and the formation of humic substances that penetrate the leachate [5].

It is generally known that the leachates contain different contaminants [6], including: biodegradable and non-biodegradable organic substances, microorganisms, heavy metals, chlorinated organic and inorganic salts, which are mostly dangerous to the environment and human health. The results of tests carried out on the leachate from eight landfills in France indicate that they react with fulvic acids to form macromolecular complexes with them [7]. The leachates of landfills, as a result of leaching of pollutants from the landfills and infiltration into the soil, is a source of potential contamination of underground and surface waters. Some types of organic leaching substances interact with heavy metals and become their carriers [8-10]. Studies have shown that the concentration and composition of leached pollutants depend not only on the type of waste being deposited but also on the time of landfilling. The leachate can be divided into: young, medium and old. The old leachates is characterized by a high content of organic substances with considerable resistance to biodegradation. These are high molecular weight substances. The humic acids of the old leachate are characterized by a higher fluorescence intensity [11]. The leachate from landfills are directed to biological municipal sewage treatment plants. The humic substances contained in them do not undergo biochemical degradation, they are partially adsorbed on the activated sludge, they are partially subject to further humification and finally they are discharged with the treated wastewater to the ground and surface waters.

\section{Characteristics of municipal waste landfill in Promnik}

The municipal waste landfill is located approximately $17 \mathrm{~km}$ north-west of the center of Kielce, in the village of Promnik, in the Strawczym municipality, in the Świętokrzyskie province.

In the landfill, processed municipal waste and non-hazardous waste are deposited, from group 19 05, $1906,1908,19$ 12, 2002 and 2003 according to the waste catalog contained in the Regulation of the Minister of Environment of December 9, 2014 on the catalog waste (Journal of Laws 2014 item 1923), in an amount not exceeding 122,000 Mg per year [12]. Wastes are deposited in layers, compacted with compactors to a layer of about $1.35-1.50 \mathrm{~m}$ and insulated with a mineral layer with a thickness of $0.15-0.20 \mathrm{~m}$. After the exploitation, the area will be reclaimed [12].

The landfill is degassed with a system of degassing wells, and the captured biogas is directed to a small power plant in order to obtain energy [12].

Waters and leachates are captured through a drainage system consisting of a perforated pipes, a discharge pipeline and an underground pumping station. The leachates from the communal waste landfill are collected in two connected tanks, recirculated to the currently operated landfill part or exported to the Sewage Treatment Plant in Sitkówka. The annual amount of leachate produced is approximately $40,000 \mathrm{~m}^{3}$ [12]. 


\section{Material and methods}

Samples were collected permanently, in the month of December from two connected tanks for leachate, with a total capacity of approx. $800 \mathrm{~m}^{3}$. The tank is located near the active third sector of the landfill. It can be assumed that the collected sample represented leachate collected for at least 2 months. The total volume of the collected and averaged sample was $20 \mathrm{~L}$.

\section{Extraction of fulvic acids}

A sample of leachate was acidified to $\mathrm{pH} \leq 2$ with $\mathrm{HCl}$. After 24 hours, the filtrate was filtered through a medium thickness filter with glass balls $<0.5 \mathrm{~cm}$ in diameter and passed through the ionic bed at a rate of about $1 \mathrm{~L} / \mathrm{hr}$. The volume of leachate directed to the ionic bed was $20 \mathrm{~L}$.

Then $\mathrm{NaOH}$ solution was directed onto the ionite to desorb adsorbed humic acids. To remove $\mathrm{NaOH}$ from the solution and obtain pure FAs in the hydrogen form, the effluent (eluent) was directed to the cation exchange bed in the hydrogen form. The resulting leach was concentrated in a vacuum evaporator at a vacuum of 350 bar and a temperature of $85^{\circ} \mathrm{C}$. The leakage was then evaporated on a water bath at $100^{\circ} \mathrm{C}$ to give a dry weight of FAs. FAs were obtained according to the method accented by the International Humic Substances Society (IHSS).

Analysis of carbon, hydrogen and nitrogen content was done using a chromatographic detection technique (elemental analysis). For the analysis used from 5 to $10 \mathrm{mg}$ of sample. The analysis of the remaining elements was done using X-ray fluorescence (XRF). The analysis was carried out in a powder analysis vessel on $4 \mu \mathrm{m}$ thick Proline film. Brune's ED-XRF spectrometer, Bruker's S8 Tiger spectrometer and Thermo's EA Flash element analyzer were used. The ash designation was done by thermogravimetric method using the SDT Q600 Thermogravimeter from TA Instruments. The heating rate was $10^{\circ} \mathrm{C} / \mathrm{min}$ to $700^{\circ} \mathrm{C}$ in airflow of $100 \mathrm{ml} / \mathrm{min}$. For the analysis used from 5 to $10 \mathrm{mg}$ of sample. Identification of compound was made using FT-IR with ATR. The spectral range was $65-4000 \mathrm{~cm}^{-1}$ at $1 \mathrm{~cm}^{-1}$ resolution and 32 scans. The Thermo Nicolet FT-IR iS10 spectrophotometer was used.

\section{Results and discussion}

Leachates from the Promnik municipal landfill were characterized by dark brown color and unpleasant odor. After filtration and ion exchange, the leachates partially lost coloration, turning the color to light brown. From $905.6 \mathrm{mg}$ of fulvic acid with $1 \mathrm{~L}$ of leachate were obtained. The extracted FAs formed a clear brown solution with water. Dried FAs were subjected to qualitative analysis. The elemental composition of the obtained FAs is shown in Table 1, the atomic quotient in Table 2, and the micropollutants in Table 3.

Table 1. Elemental composition of FAs coming from leachate [\%].

\begin{tabular}{|c|c|c|}
\hline Elemental composition & Content [\%] & Literature Content [\%] \\
\hline $\mathrm{C}$ & 37.07 & $45.6-55.7$ \\
\hline $\mathrm{H}$ & 3.31 & $6.2-9.6$ \\
\hline $\mathrm{N}$ & 3.08 & $1.0-12.0$ \\
\hline $\mathrm{S}$ & 4.09 & $1.53-1.86$ \\
\hline $\mathrm{O}$ & 52.45 & $29.6-50.0$ \\
\hline
\end{tabular}

${ }^{a}$ Based on 6 different landfills [13] 
The extracted FAs were slightly different in composition compared to the literature data. They contained less carbon but more sulfur and oxygen. The data may indicate a low degree of humification and landfilling of waste containing a significant amount of sulfur, which creates the structure of the FA molecule, and may additionally be their trace contaminations. The content of hydrogen and nitrogen was within the range specified by the authors. Comparison with other values [13] in literature is presented in Table 1.

For detailed information on $\mathrm{FA}$, molar ratios $\mathrm{H} / \mathrm{C}, \mathrm{O} / \mathrm{H}, \mathrm{O} / \mathrm{C}$ and $\mathrm{C} / \mathrm{N}$ were calculated. The atomic ratios are convergent with the research of other authors, and slight differences result from the creation of different elementary compositions related to the environmental conditions in which the humification process takes place [14]. The results are shown in Table 2. $\mathrm{H} / \mathrm{C}$ atomic ratio allows to determine the aromaticity and maturity of acids [15-17]. With the age of the landfill, the degree of maturity and aromatic condensation of FAs increases [5]. The $\mathrm{H} / \mathrm{C}$ ratio is 1.07 and is within the range of literature data. This value suggests that the obtained FAs is characterized by moderate maturity $[15,18]$.

The studies of Kukkonen J. [19], and Perminowa and others [20] on FAs, confirmed the crucial importance of the aromatic core in the binding of impurities. A large number of aromatic groups in a molecule usually means high adsorption capacity of hydrophobic compounds. This explains why the acids obtained easily adsorb pollutants present in the leachate.

Table 2. Atomic ratios of the fulvic substances from leachate.

\begin{tabular}{|c|c|c|}
\hline \multirow{2}{*}{ Atomic ratio } & Atomic ratios & Literature $^{\mathrm{a}}$ \\
\hline & \multicolumn{2}{|c|}{ Calculated as mole fraction } \\
\hline $\mathrm{H} / \mathrm{C}$ & 1.07 & $0.90-2.53$ \\
\hline $\mathrm{O} / \mathrm{H}$ & 0.99 & - \\
\hline $\mathrm{O} / \mathrm{C}$ & 1.06 & $0.40-0.78$ \\
\hline $\mathrm{C} / \mathrm{N}$ & 14.04 & $4.35-33.33$ \\
\hline
\end{tabular}

a Based on 6 different landfills $[13,14,15]$

The molar $\mathrm{O} / \mathrm{H}$ quotient is used as an indicator oxidation of acids [21]. Therefore, the $\mathrm{O} / \mathrm{H}$ ratio for tested FAs of 0.99 indicates a low degree of humification. For comparison, the average values of the ratio of FAs extracted from river sediments and lakes in China range from 5.4 to 9.1 [14]. The high difference results from the duration of the decomposition processes of organic compounds. Bottom sediments are characterized by a high content of organic compounds, deposited for many years on the bottoms of rivers and lakes, creating optimal conditions for the humification process. The low $\mathrm{O} / \mathrm{H}$ ratio extracted from $\mathrm{FAs}$ is caused by several factors. Firstly, the waste has been stored for only 33 years, and the leachate collected was a homogenized solution from 3 landfill parts. It can be assumed that the largest amounts of leachates came from the quarters no. II of the second stage, i.e. the currently exploited part, where waste decomposition processes only begin to take shape.

$\mathrm{The} \mathrm{O} / \mathrm{C}$ ratio is an indicator of the carbohydrate and carboxylic acid content in the humic substance molecule [14]. According to literature data, the $\mathrm{O} / \mathrm{C}$ ratio ranges from 0.5 to 0.9 . FAs from the landfill showed a very high $\mathrm{O} / \mathrm{C}$ ratio, demonstrating a high $\mathrm{O}$-alkyl and carboxylic acid composition, as well as low melting of aromatic condensation and the aliphatic nature of the molecule. In addition, the indicator determines the degree of humification, which should be interpreted as follows: increased humification causes an increase in organic carbon and oxygen decrease, which translates into a decrease in the $\mathrm{O} / \mathrm{C}$ ratio [21]. The $\mathrm{O} / \mathrm{C}$ ratio is confirmed by the low degree of humification of FAs. Research on changes in $\mathrm{O} / \mathrm{C}$ quotients in FAs from landfill leachates confirms the correlation of the landfilling age with the number of functional groups and the degree of aromatic condensation. With the age of waste landfilling, the number of functional groups decreases, and the degree of aromatic condensation increases [5]. 
Analyzing the quotient of carbon to nitrogen, can determine the directions and intensity of transformation processes of organic matter and nitrogen compounds [22]. In most soils, the $\mathrm{C} / \mathrm{N}$ ratio ranges from 10 to 15 and it means the balance of organic matter decomposition with the synthesis and accumulation of new organic matter. As the rate or degree of humufication increases, the $\mathrm{C} / \mathrm{N}$ ratio will decrease. Atomic ratios between 10 and 15 are commonly regarded as an index characterizing well-developed FAs [23]. The resulting $\mathrm{C} / \mathrm{N}$ ratio of 14.04 clearly shows that the organic material in the landfill is largely stabilized.

Table 3. Micropollutants analysis of FAs from leachate of Promnik landfill.

\begin{tabular}{|c|c|c|c|c|c|}
\hline Element & Symbol & Content, \% & Element & Symbol & Content, \% \\
\hline Chlorine & $\mathrm{Cl}$ & 4,47 & Iron & $\mathrm{Fe}$ & 0,07 \\
\hline Sodium & $\mathrm{Na}$ & 1,66 & Praseodymium & $\operatorname{Pr}$ & 0,05 \\
\hline Silicon & $\mathrm{Si}$ & 0,91 & Scandium & $\mathrm{Sc}$ & 0,05 \\
\hline Bromine & $\mathrm{Br}$ & 0,85 & Aluminium & $\mathrm{Al}$ & 0,01 \\
\hline Phosphorus & $\mathrm{P}$ & 0,65 & Sickel & $\mathrm{Ni}$ & $<0,01$ \\
\hline Calcium & $\mathrm{Ca}$ & 0,36 & Potassium & $\mathrm{K}$ & $<0,01$ \\
\hline Magnesium & $\mathrm{Mg}$ & 0,11 & Barium & $\mathrm{Ba}$ & $<0,01$ \\
\hline
\end{tabular}

In the analyzed elements constituting FAs micropollutants, two leading ones can be distinguished - chlorine (4.47\%) and sodium (1.66\%). Silicon, bromine and phosphorus $(<1 \%)$ had much smaller share. The remaining elements studied constituted a small fraction of the total sample content $(<0.5 \%)$.

Ash content in extracted FAs accounted for $27.15 \%$ of the total mass, which indicates high contamination with inorganic substances, the value of which depends on the extraction of acids. In the Table 3 shows some micro-pollutants. In addition, in the elemental composition of FAs, there were many elements commonly regarded as toxic. Negative functional groups, found in parts of aliphatic FAs, easily adsorb heavy metals and other toxic substances.

\section{Infrared spectrum}

The FT-IR spectra of FAs extracted from leachate were analyzed.

The signal at the $2942 \mathrm{~cm}^{-1}$, adsorption band was attributed to the symmetric stretching of $\mathrm{CH}$ in $-\mathrm{CH}_{3} \mathrm{i}-\mathrm{CH}_{2}$ aliphatic chains and indicates a high proportion of aliphatic structures in the construction of fulvic acids [13,24].

A clearly marked adsorption in the band of approximately $1713 \mathrm{~cm}^{-1}$, is associated with the occurrence of $\mathrm{C}=\mathrm{O}$ carbonyl groups in peptides, aldehydes and ketones, $\mathrm{C}=\mathrm{O}$ double bonds, $\mathrm{C}=\mathrm{O}$ stretching of carbonyl groups in ketones and quinones. The occurrence of $\mathrm{C}=\mathrm{O}$ bonds confirms the moderate and high maturity of FAs $[13,25,26]$.

The band in the $1326 \mathrm{~cm}^{-1}$ range is associated with $\mathrm{C}-\mathrm{H}$ deformation in the $\mathrm{CH}_{2}$ and $\mathrm{CH}_{3}$ groups, the asymmetric COO- stretch and the C-N stretch [4, 25].

The highest intensity of adsorptive bands was found in the range of $1158 \mathrm{~cm}^{-1}$ and $1038 \mathrm{~cm}^{-1}$, this proves the vibration of alcohol functions, stretching of C-O-C carbohydrates, stretching of $\mathrm{C}-\mathrm{O}$ in polysaccharides, shocking vibrations of $\mathrm{C}-\mathrm{H}$ methyl linked to the $\mathrm{S}$ atom [13, 27]. 


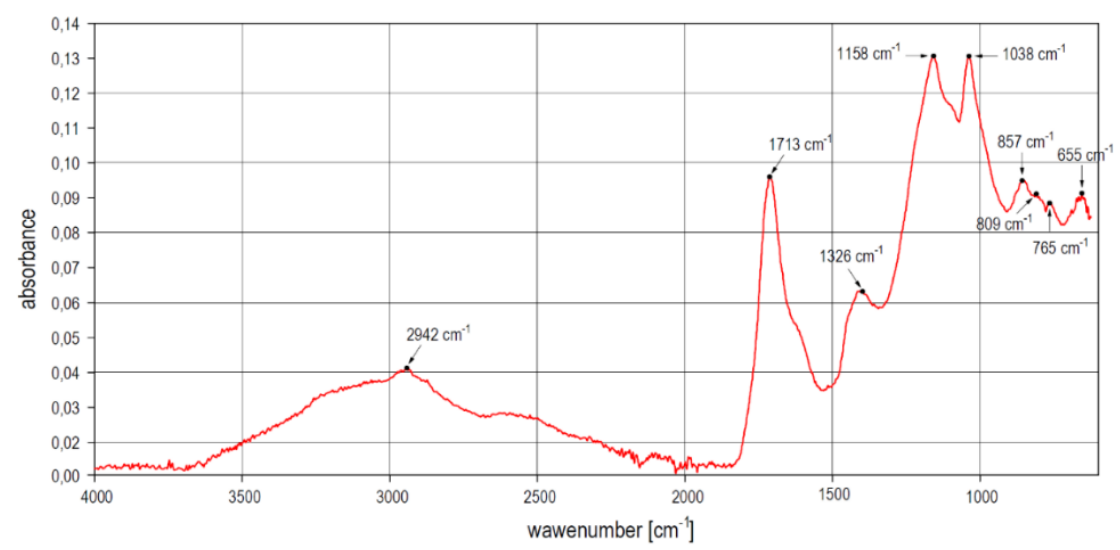

Fig. 1. Infrared spectra of FAs from leachate of Kielce landfills.

FAs showed adsorption in the $857-765 \mathrm{~cm}^{-1}$, range due to $\mathrm{N}-\mathrm{O}$ bonds with nitrogen esters, aromatic $\mathrm{C}-\mathrm{H}$ bending, $\mathrm{N}-\mathrm{H}$ vibration and vibration $\mathrm{NH}_{2}$ out of plane $[13,15]$. Bands at $655 \mathrm{~cm}^{-1}$ are associated with the presence of inorganic sulphates (S-O bends and S-O stretch, respectively) and nitrite esters $[15,25]$.

\section{Conclusions}

1. The leachate from the Promnik landfill was characterized by the presence of fulvic acids in an amount $905 \mathrm{mg} / \mathrm{L}$.

2. Sample analysis showed significant inorganic contaminants. Dry matter content after roasting was $27.15 \%$. This demonstrates the high chemical activity of the tested acids, which become carriers of toxic micro-contaminants.

3. $\mathrm{H} / \mathrm{C}, \mathrm{O} / \mathrm{H}, \mathrm{O} / \mathrm{C}$ and $\mathrm{C} / \mathrm{N}$ atomic ratios showed:

- moderate FAs maturity and low degree of humification,

- high carboxylic acid O-alkyl composition and low degree of aromatic condensation,

- an aliphatic nature of a molecule consisting mainly of an aromatic structure,

- a high degree of stabilization of organic material.

4. Infrared spectra showed a high proportion of aliphatic and aromatic structures in the study of fulvic acids and moderate maturity of FAs.

\section{References}

1. Dyrektywa Parlamentu Europejskiego i Rady 2008/98/WE z dnia 19 listopada 2008 r. w sprawie odpadów oraz uchylająca niektóre dyrektywy (Tekst mający znaczenie dla EOG) (z. Urz. UE z 22 listopada 2008 r. L 312/3 - dyrektywa ramowa). Strasburg: Dz. Urz. UE (2008)

2. D. Rozkrut, E. Adach-Stankiewicz, R. Bielak, M. Bieniek, M. Błażej, M. Jeznach, E. Kamińska-Gawryluk, L. Kursa, M. Mojsiewicz, D. Rogalińska, J. Stańczal, W. Szuchta, G. Szydłowska, W. Tkaczyk, K. Walkowska, M. Węgłowska, H. Woźniak, Mały Rocznik Statystyczny Polski (GUS, Warszawa, 448, 2018)

3. D. Bochenek, E. Gorzkowska, A. Górska, R. Józwicka, M. Klimkiewicz, A. Kulasza, B. Nowakowska, T. Pawłowska, J. Sulik, M. Wojciechowska, A. Wrzosek, Ochrona środowiska 2017 (GUS, Warszawa, 40-42, 2017) 
4. H. Wang, YN. Wang, X. Li, Y. Sun, H. Wu, D. Chen, Waste Manage. 56, 271-279 (2016)

5. C. Xiaoli, T. Shimaoka, G. Qiang, Z. Youcai, Waste Manage. 28, 5, 896-903 (2008)

6. P. Ghosh, I. S. Thakur, A. Kaushik, Ecotoxicol. Environ. Saf. 141, 259-270 (2017)

7. F. Clareta, C. Tournassata, C. Crouzeta, E. C. Gauchera, T. Schäferbc G. Braibanta, D. Guyonneta, Waste Manage. 31, 9-10, 2036-2045 (2011)

8. P. Kjeldsen, M. A. Barlaz, A. P. Rooker, A. Baun, A. Ledin, T. H. Christensen, Crit. Rev. Env. Sci. Tec. 32, 4, 297-336 (2002)

9. Y. Zhou, Y. Zhang, G. Li, T. Jiang, Powder Technol. 302, 90-99 (2016)

10. A. M. Anielak, M. Wojnicz, Arch. Environ Prot. 36, 3, 27-37 (2010)

11. C. Xiaoli, L. Guixiang, Z. Xin, H. Yongxia, Z. Youcai, Waste Manage. 32, 3, 438-447 (2012)

12. A. Siemieniec, M. Siemieniec, Instrukcja prowadzenia sktadowiska odpadów komunalnych $w$ Promniku (Kielce, 2015)

13. Y. S. Han, J. Y. Lee, C. J. Miller, L. Franklin, Waste Manage. Res. 27, 3, 233-241 (2009)

14. M. He, Y. Shi, C. Lin, J. Environ. Sci.-China. 20, 11, 1294-1299 (2008)

15. G. Qi, D. Yue, Y. Nie, Front Env. Sci. Eng. 6, 5, 711-716 (2012)

16. K. H. Kang, H. S. Shin, H. Park, Water Res. 36, 16, 4023-4032 (2002)

17. C. Xiaoli, J. Rong, W. Jun, T. Huanhuan, Z. Youcai, Chemosphere 78, 11, 1362-1367 (2010)

18. F. Delarue, S. Derenne, K. Sugitani, F. Baudin, F. Westall, B. Kremer, R. Tartese, A. Gonzales, F. Robert, Org. Geochem. 122, 140-146 (2018)

19. F. De Paolis, J. Kukkonen, Chemosphere 34, 8, 1693-1704 (1997)

20. I. V. Perminova, N. Y. Grechishcheva, V. S. Petrosyan, Environ. Sci. Technol. 33, 21, 3781-3787 (1999)

21. A. M. Gonach, M. H. El-Halafawi, T. M. El-Essawi, Alex. J. Agric. Res. 26, 3, 747-754 (1978)

22. K. Walenczak, Charakterystyka gleb naturalnej $i$ wschodniej części Wroctawia Rozprawa doktorska (Uniwersytet Przyrodniczy we Wrocławiu, Wrocław, 2011)

23. K. T. Tan, Humic Matter in Soil and the Environment: Principles and Controversies (Second Edition, 5, 90-91, 2014)

24. M. Linczar, Zesz. Nauk. AR we Wrocławiu 48, 1-79 (1985)

25. S. Huo, B. Xi, H. Yu, L. He, S. Fan, H. Liu, J. Environ. Sci.-China. 20, 4, 492-498 (2008)

26. S. Zhang, L. Yuan, W. Li, Z. Lin, Y. Li, S. Hu, B. Zhao, Chemosphere 166, 334-342 (2017)

27. M. A. Nanny, N. Ratasuk, Water Res. 36, 6, 1572-1584 (2002) 